\title{
Pengaruh Temephos Terhadap Perolehan Telur Nyamuk Aedes aegypti (L) Di Cipinang Muara Jakarta
}

\section{HASYIMI, SUWARTO, I. WALUYO, MARDIANA, SUYITNO, SUKIJO DAN SUPRIYONO}

Pusat Penelitian dan Pengembangan Ekologi Kesehatan

Jl. Percetakan Negara No. 149, Jakarta

(diterima Mei 2005, disetujui Agustus 2005)

\begin{abstract}
The Effect of Abaticidal Ovitrap on Aedes aegypti (L) Egg Finding in Cipinang Muara, East Jakarta. A study on the effect of abaticidal ovitrap on Aedes aegypti egg findings was carried out in Cipinang Muara, East Jakarta from October 1997 until January 1998. Twenty five houses were designed as treatment objects. Ovitrap were sit indoor and outdoor in each house. Seventy five houses were used as buffer. People in this area were trained on how to set up and to manage their ovitrap. Control area in the same "Rukun Warga (RW)" was selected and treated with the same way. The result has shown that egg number from the treated area has significantly reduced and less than the egg number in the control area. The mean the number of eggs found in the first year was $20.8 \mathrm{eggs}$, while in the second year was 38.8 eggs. The average ovitrap index (OI) in the first year was $38.8 \%$, while in the second year was $49.4 \%$. Abate did not affect the activity of oviposition and the number of laid eggs.
\end{abstract}

KEYWORD : Abaticidal ovitrap, Aedes aegypti and Abate

\section{PENDAHULUAN}

\section{Aedes aegyti (L) (Diptera:} Culicidae) merupakan vektor utama penyakit demam berdarah dengue (DBD) di daerah perkotaan. Stadium pradewasa $A$. aegypti ditemukan pada genangan air jernih pada bejana buatan manusia yang berada di dalam dan di luar rumah (Nelson 1986). Populasi vektor DBD dapat diketahui dari hasil penangkapan nyamuk dewasa, koleksi larva dan penggunaan perangkap telur (ovitrap). Cara yang terakhir disebutkan terutama untuk daerah yang kepadatan vektornya rendah dan larvanya sulit ditemukan. Pengendalian larva nyamuk ini dapat dilakukan dengan pemberantasan sarang nyamuk (PSN) dan atau penaburan temephos (Abate $\circledast)$ ke dalam penampungan-penampungan air.

Temephos adalah insektisida golongan organophosphate dan sangat populer sebagai larvisida untuk nyamuk. Temephos termasuk dalam kelompok 
fenil, mempunyai sifat residual lebih lama (Wirawan 2006), dan stabil pada temperatur $25^{\circ} \mathrm{C}$ di alam dan pada air garam (Sudiyono 1983). Di Indonesia dan beberapa negara lain, pemberantasan vektor $\mathrm{DBD}, A$. aegypti dengan menggunakan temephos telah dilakukan.

Pengaruh pembubuhan temephos terhadap peletakan telur $A$. aegypti kemungkinan ada atau tidak ada sama sekali. Dampak penaburan temephos terhadap peletakan telur nyamuk $A$. aegypti belum banyak diketahui. Namun, penelitian yang menggunakan autodial ovitrap (perangkap telur) untuk mengurangi dan mengendalikan $A$. aegypti di daerah urban di negara Singapura pernah dilakukan oleh Harword pada tahun 1979. Salah satu kesimpulannya menyatakan bahwa dari kontainer domestik yang terdapat di 115 rumah di daerah penelitian, rata-rata terkumpul larva sebanyak 48 per minggu. Sementara yang menggunakan ovitrap dapat terkumpul larva rata-rata sebanyak 550 (Harword et al 1979 ).

Tulisan ini dimaksudkan untuk mendapatkan informasi yang lebih mendalam tentang pengaruh penggunaan temephos terhadap perilaku nyamuk dalam meletakkan telurnya. Untuk mendapatkan hasil yang lebih baik maka dalam penelitian ini digunakan ovitrap yang dibubuhi temephos.

\section{BAHAN DAN METODE}

\section{Daerah Penelitian}

Penelitian dilakukan di wilayah Rukun Warga (RW) 011 Kelurahan Cipinang Muara, Kecamatan Jatinegara, Jakarta Timur. Luas Kelurahan Cipinang Muara adalah 2,9 km $\mathrm{km}^{2}$, dan terdiri atas 16 RW, 188 Rukun Tetangga (RT). Jumlah Kepala Keluarga (KK) 14.374 yang terdiri atas 61.215 jiwa. Kepadatan penduduk 21.108,62 jiwa/ km (Sumber: Biro Pusat Statistik/BPS Jakarta Timur).

\section{Karakteristik ovitrap}

Ovitrap yang digunakan berupa ember plastik berwarna hitam dengan dinding kasar dan bergelombang dengan ukuran diameter mulut (atas) $14 \mathrm{~cm}$, alas (bawah) $8 \mathrm{~cm}$ dan tingginya $13 \mathrm{~cm}$. Ovitrap yang digunakan di daerah perlakuan diisi dengan larutan temephos 1 ppm dan yang digunakan untuk pembanding diisi air saja, masing-masing sebanyak sepertiga volume nya. Di dalam masing-masing ovitrap dimasukkan kain katon berwarna merah yang berukuran $3,5 \mathrm{~cm} \times 14 \mathrm{~cm}$.

\section{Sampel Penelitian}

\section{a. Daerah Perlakuan}

Rumah-rumah yang dilibatkan dalam penelitian di daerah perlakuan dipasangi ovitrap yang dibubuhi temephos. 
Rumah-rumah untuk perlakuan terdiri atas 25 rumah penduduk yang masingmasing di pasangi 2 buah ovitrap. Satu buah ovitrap diletakkan di luar rumah (outdoor) dan lain nya diletakkan di dalam rumah (indoor). Ke 25 rumah ini terletak di wilayah RT 01 dan 02, RW 011. Dua puluh lima rumah ini dikelilingi oleh 75 rumah penyangga yang dipasangi ovitrap bertemephos di luar dan di dalamnya.

\section{b. Daerah pembanding}

Daerah pembanding terletak di wilayah RT 04 dan 05, RW 011. Daerah ini berjarak kurang lebih 100 meter dari daerah perlakuan, dan dipisahkan oleh jalan umum yang setiap pagi berubah fungsi menjadi pasar.

\section{Cara kerja}

Penelitian dilakukan oleh tim peneliti Pusat Penelitian dan Pengembangan (Puslitbang) Ekologi Kesehatan Balitbangkes dan bekerja sama dengan remaja yang tergabung dalam organisasi Karang Taruna setempat. Untuk masing-masing daerah perlakuan dan pembanding (termasuk penyangga) digunakan 200 ovitrap, sehingga di perlukan 400 buah. Kain merah sebagai peletak telur nyamuk, masing-masing di masukkan ke dalam ovitrap dengan posisi tegak. Salah satu ujung tiap-tiap kain tercelup dalam air/larutan temephos sedang ujung lainnya dijepit ke mulut atau cukup diikatkan pada tangkai ovitrap. Satu buah ovitrap yang sudah terangkai diletakkan dekat penampungan air di dalam masing-masing rumah dan satu buah lagi di luar rumah (di peranda). Kain merah diambil setiap sembilan hari pada jam 9.00-11.00 WIB. Pengambilan kain dilakukan sebanyak 9 kali sebagai ulangan. Kain dimasukkan dalam kantong plastik ukuran es mambo kemudian dibawa ke laboratorium Puslit bang Ekologi Kesehatan, Jakarta. Telur kemudian dihitung dibawah mikroskop binokuler, sehingga didapatkan data rata-rata telur per ovitrap dan ovitrap index

Tabel 1. Ovitrap index (OI) dan perolehan telur Ae. aegypti rata-rata per ovitrap tahun $1997 / 1998$ di Kelurahan Cipinang Muara, Jakarta Timur.

\begin{tabular}{|c|c|c|c|c|c|c|c|c|c|c|c|c|}
\hline \multirow{3}{*}{ Ulangan } & \multicolumn{6}{|c|}{ Perlakuan } & \multicolumn{6}{|c|}{ Pembanding } \\
\hline & \multicolumn{2}{|c|}{ Dalam } & \multicolumn{2}{|c|}{ Luar } & \multicolumn{2}{|c|}{ Kombinasi } & \multicolumn{2}{|c|}{ Dalam } & \multicolumn{2}{|c|}{ Luar } & \multicolumn{2}{|c|}{ Kombinasi } \\
\hline & Ol & $\begin{array}{c}\text { Telur } \\
\left({ }^{*}\right)\end{array}$ & OI & $\begin{array}{c}\text { Telur } \\
\left({ }^{\star}\right)\end{array}$ & Ol & $\begin{array}{c}\text { Telur } \\
\left({ }^{*}\right)\end{array}$ & Ol & $\begin{array}{c}\text { Telur } \\
(*)\end{array}$ & OI & $\begin{array}{c}\text { Telur } \\
\text { (*) }\end{array}$ & OI & $\begin{array}{c}\text { Telu } \\
\left({ }^{*}\right)\end{array}$ \\
\hline I. & 44 & 5,8 & 44 & 3,2 & 44 & 4,5 & 38,9 & 4,6 & 38,9 & 6,5 & 18,9 & 5,6 \\
\hline II. & 24 & 5.1 & 32 & 11,1 & 28 & 8,1 & 8,3 & 1,2 & 12,5 & 9,1 & 10,4 & 5,1 \\
\hline III. & 26,3 & 2,8 & 37,5 & 10,6 & 32 & 6.7 & 39,1 & 0,8 & 56,5 & 3,1 & 47,8 & 1,9 \\
\hline IV. & 24 & 2,4 & 44 & 4,9 & 34 & 3,6 & 14,3 & 2,2 & 14,3 & 1,4 & 14,3 & 1,8 \\
\hline V. & 38,9 & 26,9 & 30,9 & 24,1 & 34 & 25,9 & 16 & 12,4 & 20 & 7,5 & 18 & 9,9 \\
\hline Vi. & 60 & 16,7 & 28 & 11,5 & 44 & 14,1 & 32 & 14,3 & 20 & 7.6 & 26 & 11 \\
\hline VII. & 30,9 & 13,1 & 54,5 & 31,3 & 42,4 & 22,4 & 20 & 18,8 & 30 & 14,9 & 20 & 16,8 \\
\hline VIII. & 42 & 51,2 & 38 & 37,9 & 40 . & 44,6 & 13,6 & 7 & 60,9 & 36,4 & 37,8 & 21,7 \\
\hline $\mathrm{IX}$ & 40 & 60,5 & 60,8 & 55,9 & 50.5 & 58,1 & 24 & 9,2 & 35 & 8,4 & 30 & 8,5 \\
\hline $\begin{array}{r}\text { Rata- } \\
\text { rata }\end{array}$ & 36,6 & 20,5 & 41,1 & 21,2 & 38,8 & 20,8 & 22,9 & 7,9 & 32,1 & 10,5 & 24,8 & 9,2 \\
\hline
\end{tabular}

- Perolehan telur rata-rata per ovitrap. 
(OI). Telur dipisahkan berdasarkan waktu dan alamat rumah tempat telur diambil, kemudian ditetaskan. Larva yang diperoleh diidentifikasi untuk memastikan bahwa larva-larva tersebut berasal dari telur $A$. aegypti. Penghitungan kemaknaan secara statistik dengan menggunakan chisquare.

\section{HASIL DAN PEMBAHASAN}

Pada tahun 1969, ovitrap hasil modifikasi Amerika telah dipergunakan sebagai pelengkap pengendalian vektor A. aegypti Di Pelabuhan Udara Internasional Paya Lebar, Singapura. Hasilnya memperlihatkan bahwa ovitrap dapat digunakan untuk mengurangi padat populasi nyamuk $A$. aegypti sehingga tidak tersebar lagi di pelabuhan tersebut selama 6 tahun dengan batas areal $800 \mathrm{~m}^{2}$ (Chan et al. 1977).

Mekanisme kerja larvisida temephos adalah menghambat suatu enzim yang sangat penting dalam sistem syaraf yang disebut dengan kolinesterase (Ch E). Enzim ini menjadi terfosforilisasi ketika terikat dengan $\mathrm{OP}$ dan ikatan ini bersifat tetap (irreversible). Penghambatan ini menyebabkan akumulasi asetilkolin pada sinapsis dan mengakibatkan kejang otot dan akhirnya paralisis otak lumpuh (Wirawan 2006). Hasil penelitian pada tahun pertama (1997/1998) disajikan pada Tabel 1. Pada Tabel tersebut, tampak bahwa OI kombinasi yang merupakan rata-rata dari ulangan ovitrap di dalam dan di luar untuk daerah perlakuan adalah sebesar $38,8 \%$, sedangkan OI kombinasi di daerah pembanding hanya $24,8 \%$. Secara statistik, perbedaan ini sangat nyata $\left(X^{2}=38,5 ; P>0,05\right)$. Perihal telur yang diperoleh, kombinasi luar-dalam rumah dan merupakan rata-rata per ovitrap adalah sebesar 20,8 butir, sedangkan pada pembanding sebesar 9,2 butir. Secara statistik, nilai keduanya berbeda nyata $\left(\mathrm{X}^{2}=31,8 ; \mathrm{P}>0,05\right)$. Pada tahun pertama ini OI dan perolehan

Tabel 2. Ovitrap index (OI) dan perolehan telur Ae. aegypti rata-rata per ovitrap tahun $1998 / 1999 \mathrm{di}$ Kelurahan Cipinang Muara, Jakarta Timur.

\begin{tabular}{|c|c|c|c|c|c|c|c|c|c|c|c|c|}
\hline \multirow{3}{*}{ Ulangan } & \multicolumn{6}{|c|}{ Perlakuan } & \multicolumn{6}{|c|}{ Pembanding } \\
\hline & \multicolumn{2}{|c|}{ Dalam } & \multicolumn{2}{|c|}{ Luar } & \multicolumn{2}{|c|}{ Kombinasi } & \multicolumn{2}{|c|}{ Dalam } & \multicolumn{2}{|c|}{ Luar } & \multicolumn{2}{|c|}{ Kombinasi } \\
\hline & OI & Telur & Ol & Telur" & OI & Telur* & Ol & Telur" & Ol & Telur* & ol & Telur \\
\hline $\begin{array}{l}\text { I. } \\
\text { II. } \\
\text { III. } \\
\text { IV. } \\
\text { V. } \\
\text { Vi. } \\
\text { VIII. } \\
\text { VIII. } \\
\text { IX. }\end{array}$ & $\begin{array}{c}48 \\
45,8 \\
29,2 \\
36 \\
48,3 \\
44 \\
56 \\
42,3 \\
52\end{array}$ & $\begin{array}{c}18,1 \\
28,8 \\
29,3 \\
27,3 \\
49,5 \\
27,5 \\
5,2 \\
22,8 \\
24,6\end{array}$ & $\begin{array}{c}56 \\
66,6 \\
54,2 \\
48 \\
54,2 \\
38,3 \\
60 \\
46,1 \\
44\end{array}$ & $\begin{array}{l}22,2 \\
47,4 \\
38,8 \\
43,7 \\
40,3 \\
51,2 \\
31,4 \\
35,2 \\
60,7\end{array}$ & $\begin{array}{c}52 \\
56,3 \\
41,7 \\
52 \\
51,5 \\
41,2 \\
58 \\
44,2 \\
48\end{array}$ & $\begin{array}{c}20,2 \\
38.1 \\
34,0 \\
35,5 \\
45 \\
39 \\
18 \\
29 \\
42,7\end{array}$ & $\begin{array}{c}52 \\
13,4 \\
28 \\
20 \\
59 \\
13,0 \\
44 \\
52 \\
48\end{array}$ & $\begin{array}{c}29 \\
17,9 \\
27,6 \\
3,9 \\
26 \\
14,6 \\
7,8 \\
6,4 \\
26,1\end{array}$ & $\begin{array}{c}36 \\
30,1 \\
52 \\
52 \\
52,2 \\
34,8 \\
68 \\
40 \\
68\end{array}$ & $\begin{array}{l}40,8 \\
12,5 \\
57,5 \\
18,7 \\
30,5 \\
62,2 \\
28,7 \\
11,3 \\
6,7\end{array}$ & $\begin{array}{c}44 \\
21,7 \\
40 \\
36 \\
55,6 \\
24,1 \\
56 \\
46 \\
58\end{array}$ & $\begin{array}{c}34,9 \\
15,2 \\
42,5 \\
11,3 \\
20,3 \\
38,2 \\
18,3 \\
8,9 \\
16,4\end{array}$ \\
\hline Rata-rata & 46,8 & 25,9 & 51,9 & 41,2 & 49,4 & 33,5 & 36,6 & 17,7 & 48,1 & 29,9 & 42,4 & 23,8 \\
\hline
\end{tabular}

- Perolehan telur rata-rata per ovitrap. 
telur per ovitrap di daerah perlakuan lebih besar dibandingkan pada daerah pembanding. Apabila OI di luar rumah dibandingkan dengan OI di dalam rumah, ditemukan bahwa OI di luar rumah sebesar $41,1 \%$, sedangkan di dalam rumah sebesar 36,6\%. Angka di luar rumah lebih besar daripada di dalam rumah, tetapi secara statistik tidak berbeda nyata $\left(X^{2}=1,3 ; P<0,05\right)$. Apabila perolehan telur di luar rumah dibandingkan dengan perolehan yang di dalam rumah, ditemukan bahwa di luar rumah telur yang diperoleh per ulangan per ovitrap rata-rata sebesar 21,2 butir, sementara yang di dalam rumah sebesar 20,5 butir. Jumlah telur per ovitrap di luar rumah lebih besar dibanding dengan di dalam rumah walaupun tidak berbeda nyata $\left(X^{2}=5,7 ; \quad P<0,05\right)$. Hasil penelitian Erda et al. (1990), Lestari et al. (1991) dan Hasyimi et al. (1993) menyimpulkan bahwa berdasarkan lokasi penempatan, ovitrap yang diletakkan di luar rumah memberikan hasil OI yang relatif lebih tinggi dibandingkan dengan perolehan di dalam rumah. Demikian pula halnya dengan perolehan rata-rata jumlah telur. Jumlah perolehan telur di luar rumah lebih banyak bila dibandingkan dengan yang di dalam rumah.

Hasil penelitian tahun kedua (1998/1999) disajikan pada Tabel 2. Pada tabel tersebut terlihat bahwa OI kombinasi rata-rata tiap ulangan 49,4\%. Angka ini lebih besar dibandingkan dengan OI kombinasi pembanding yang hanya $42,4 \%$, walaupun secara statistik tidak berbeda nyata $\left(X^{2}=9,07 ; \quad P<\right.$ 0,05). Perolehan telur di daerah perlakuan adalah 33,5 butir, sementara pada pembanding hanya 23,8 butir. Nilai-nilai tersebut menunjukkan perbedaan yang sangat nyata $\left(X^{2}=\right.$ 39,45; P >0,05).

OI di luar rumah untuk daerah perlakuan rata-rata sebesar $51,9 \%$ per ovitrap, sementara di dalam rumah ratarata sebesar $46,8 \%$ per ulangan. Jadi, OI luar rumah lebih besar daripada di dalam rumah walaupun nilainya tidak berbeda nyata $\left(X^{2}=0,006 ; P<0,05\right)$.

Dari uraian diatas dapat dikatakan bahwa kondisi OI dan jumlah telur yang diperoleh di daerah perlakuan, pada tahun pertama dan tahun kedua memperlihatkan hal-hal sebagai berikut: 1) OI luar rumah lebih besar daripada OI dalam rumah; dan 2) Jumlah rata-rata telur yang diperoleh dari luar rumah lebih besar daripada yang diperoleh dari dalam rumah. Hasil ini berbeda dengan hasil penelitian Hasyimi et al. (2004) yang dilakukan di Kelurahan Rawajati, Jakarta Selatan, khususnya di daerah perlakuan. Mereka melaporkan bahwa jumlah telur $A$. aegypti yang terperangkap pada ovitrap yang diletakkan di luar rumah nyata lebih sedikit dibandingkan dengan yang di dalam rumah.

Apabila diperhatikan data yang diperoleh di daerah pembanding saja, (Tabel 1 dan 2) terlihat bahwa kondisi di daerah pembanding mempunyai pola yang sama dengan daerah perlakuan. 
Tetapi, angka-angka di daerah perlakuan memperlihatkan nilai yang lebih besar dibandingkan dengan di daerah pembanding.

\section{KESIMPULAN}

Dari penelitian ini dapat disimpulkan bahwa temephos tidak mengurangi perolehan jumlah telur bahkan cenderung menarik/mengundang nyamuk $A$. aegypti untuk meletakkan telurnya. Temephos juga tidak mengurangi aktivitas nyamuk dalam meletakkan telur pada ovitrap. Temephos juga tidak merubah pola kesenangan bertelur $A$. aegypti, yaitu lebih senang di luar rumah daripada di dalam rumah.

\section{SARAN}

Penelitian ini berupa penelitian berskala kecil serta hanya menggunakan satu macam larutan temephos. Selain banyak faktor alam dan non alam yang mempengaruhinya. Perlu diketahui lebih lanjut tentang konsentrasi temephos yang dapat mempengaruhi perilaku nyamuk untuk bertelur. Untuk mendapatkan informasi yang lebih rinci, perlu dilakukan penelitian lebih lanjut yang bersifat laboratoris.

\section{DAFTAR PUSTAKA}

Chan KJ . 1972-1973. The eradication of Aedes aegypti of the Singapure paya Lebar international air port. Vector control in South East Asia. Proc.I Seameo Tropmed Worksjbop Singapore pp. 85-88.

Chan Kl, Ng Sk, Tan Kk, 1977. An autocidal ovitrap for the control and possible eradication of Aedes aegypti. South Asian.J.Trop.Med. Pub. Health. 8:36-62

Lestari EW, M Hasyimi, S. Sukowati. 1991. Penggunaan ovitrap untuk pemantauan populasi Aedes aegypti di Jakarta Pusat. Prosiding Konggres dan Seminar nasional Biologi. Vol. II Bogor h.148-153.

Erda. 1990. Pengaruh bahan dan warna ovitrap terhadap perletakan telur Aedes aegypti. Seminar Parasitologi Nasional. Pandaan, Juni 1990.

Harword Rf, James. 1979. Entomology and Human and Animal health. New York: 4 Mac Milan Publishing Co. Inc.; 169.

Hasyimi M, EW Lestari, S. Supratman. 1993. Kesenangan bertelur Aedes spesies. Majalah Sanitas. Vol.II No. 3 pp. 163-165.

Hasyimi M, I Waluyo, Suyitno, Sukijo 2004. Perolehan telur Ae. aegypti per ovitrap yang dibubuhi temephos di Kelurahan Rawajati Jakarta Selatan. JEK.. 3 (3): 113-117.

Nelson Ms. 1986. Aedes aegypti : Biology and Ecology. Washington DC: Pan America Health Org.

Sudiyono. 1983. Temephos ( Abate, OMS 786).Dep.Kes. RI.

Wirawan IS. 2006. Insektisida Permukiman, dalam Hama Permukiman Indonesia Pengenalan, Biologi dan Pengendalian. Hal. 315. 